\title{
ROLE OF MUNICIPALITIES IN THE URBAN PLANNING OF POST-OIL GULF CITIES: THE CASE OF DUBAI, UNITED ARAB EMIRATES
}

\author{
EMAN ASSI \\ American University of Ras Al Khaimah, United Arab Emirates
}

\begin{abstract}
Dubai is a highly memorable place: The image in your mind matches up with a colorful history of a pearl diving, fishing, gold trading settlement. Since the beginning of the 20th century, trade was the driving force behind its wealth and success. With little or no resources, Dubai became the main centerport in the Persian Gulf, the busiest regional trading center. The first Dubai Plan was assigned to John Harris in 1960, by his highness Sheikh Rashid Bin Saeed Al Maktoum. This paper aims to assess how John Harris' developmental plans addressed the vision of his Highness to transfer Dubai into a modern, global city. In doing so, the author attempted to understand the process of transformation and its impact on the cultural and social changes of the city. More specifically, the author answers the following questions: What was the main focus of these plans? How were these plans implemented on the ground? What were the main challenges that faced John Harris and Dubai Municipality to achieve the goals set? The author researched documents and archives of Dubai Municipality, meeting minutes of the Municipality Council and Dubai Monthly Journal, which were very helpful in looking in depth at this period. The author concludes that urban development, when in a state involved with certain power, could be more influential at nation-building, in shaping the urban city landscape. Dubai's urbanization did not face conflicts between old and new, like other Arabic cities. For John Harris, the focus was on both the functional and aesthetic aspect, to integrate the conservation of historic buildings as part of a living process, in which good new buildings were encouraged.
\end{abstract}

Keywords: city planning, cultural heritage, Dubai, historic architecture, John Harris, Persian Gulf, United Arab Emirates, urban development, urban planning.

\section{INTRODUCTION}

Dubai Municipality, established in 1957, was not one of the earliest municipalities in the Persian Gulf [1]. The first one was the city of Manama Municipality in the Kingdom of Bahrain, established in 1919, followed by Kuwait City Municipality, established in 1930. Although Gulf municipalities share the same reason for their establishment, the organizational structure they adopted, the responsibilities they carried to address the newly emerging situation, they still differed in their effectiveness to address rapid changes, the level of decentralization given to the municipal council, and their programs and priorities. Within 25 years, Dubai Municipality succeeded in transferring Dubai from being a small fishing port to a modern global city, highly recognized on the world map. In 1975, Dubai was known as the jewel of the Middle East. Dubai's World Trade Centre building was the first skyscraper in the Middle East [2].

In 1960, Dubai underwent rapid physical and social changes. These changes were not generated only by oil revenue, but also expanding commerce and free trade. Dubai's population increased through immigration, to reach $445 \%$ within 15 years. According to Dubai statistics, the population had increased from 40,000 inhabitants in 1960 to 183,000 inhabitants in 1975 [3]. In the early 1960s, Dubai did not have much infrastructure, with few telephone lines, and lack of paved roads, utility networks and running water. The first house built of concrete blocks was constructed in 1956; as a large number of Dubai's inhabitants had lived in palm-frond (barasti) houses. 
The barasti quarters usually had a compound for extended families to be grouped together in clusters of related families [4]. The alleys were nowhere wide enough to let a car pass through. There was no need for wide spaces between houses since each house and compound was built to provide a maximum of privacy inside. Transport within the town was possibly only on donkey or camel until the beginning of the 1960s, when some roads were opened up by the municipality. Dubai had no cars in the early 20th century. Cars could be driven over the salt flats (Sabkhah) and along the beach at low tide, but had to be left well outside the built-up quarters of Dubai. Traffic between Dubai and Deira was largely accomplished by rowing boats (called $a b r a$ ); there were, and still are, a number of fixed landing points on either side of the creek. In the 1930s a taxi service operated in Dubai; and between Dubai and Deira, around the eastern end of the creek. Another service went between Dubai and Sharjah. Waste disposal management in Dubai at that time also was managed through the social and cultural system. Proper refuse disposal was not organized until sometime in the late 1950s, when Sheikh Rashid appointed some people to undertake this for all quarters of the city-state.

In 1939, His Highness (HH) Sheikh Saeed Bin Maktoum delegated a lot of the responsibility for domestic affairs of the City State of Dubai to his son, Rashid. Sheikh Rashid became ruler in 1958, so when funds become available to improve conditions in the sheikhdom, he initiated changes which had much in common with those proposed in $1938[5]$.

The 1950s were a period of transition for Dubai Creek, starting when the silting of the creek especially at its mouth, which forced larger boats to instead use nearby ports like Sharjah. Dubai's Ruler's decision to launch the dredging of Khor Dubai likely became the key for the future development of the city. Sheikh Rashid himself (1958-1990) institutionalized his relationship with merchants through his majlis and the court, concentrating his efforts on trade [1].

\section{SHIFTING FROM TRIBAL TO MUNICIPAL: THE GULF EXPERIENCE}

Many Arab cities were left out of the international global discourse [6], according to the globalization definition by Saasen, with focus only on cities which are nodes in the network of globalization and considered places where the global economy is being coordinated and reproduced [7]. Castells' definition also similarly identified global cities to be places in which advanced services are produced and consumed. Dubai, as an evolving city, was also not considered within this definition [8]. For Shami, Arab cities are seen as a product of people with a complicated mechanism [9].

The focus of all Gulf States in the 20th century is to find ways to shift from governance from the tribal structure adopted for many years, to a municipal governance structure that will be capable of addressing new emerging issues [6]. Before, it was impossible for these countries to survive without the tribal structure. In most cases, the tribal structure started with families united to find water, food and other resources through collective efforts: They protect them and refuse to share them with others. The emphasis on the group excluded the rise of a strong leader. Accordingly, tribal leadership is often called, according to Halem, "the first among equals", suggesting that a collective leadership in which one among a number of leaders is recognized as the most authoritative [10]. The principal leader, or sheikh, in this case, must continue to consult with his lesser colleagues [11]. The big transformation in the Gulf in the beginning of the 20th century made it difficult for the tribal structure to continue to function. This was because of the new types of responsibilities that emerged. Each had to find its own way to distinguish itself from its neighbors, while confronting local challenges to the newfound wealth and potential power [9]. 
When the Municipality of Manama in Bahrain was established according to the law issued in 1920, it had limited responsibilities and a modest budget. The first budget was in 1920 with revenue of 604 dinar and expenditures of 604 dinar. The main aim of the eight appointed municipal council members was to serve the community in their daily life, through a new reform that covered the major parts of public life, such as justice, trade and customs [12]. Their responsibilities expanded to include other duties. Later, the Bahrain municipality became responsible for everything [13].

In Kuwait, the municipality was established in 1930. The main aim was to improve the conditions of health and the social conditions of the community, through an elected municipal council. The Municipal Council had the power to make decisions that would serve the community well [14]. Its responsibilities were expanded to cover the issues of health, tax collection and management of urban development. The first master plan was laid in 1951; it included many improvements [15]. Another decree was issued in 1954, to define the role and responsibilities, as well as its organizational structure, within a certain allocated budget. Later, in 1960, another decree was issued about the beautification of the city and food safety.

\section{CREATION OF DUBAI MUNICIPALITY COUNCIL}

In 1958, HH Sheikh Saeed Bin Maktoum died, and his son Rashid, who had been largely responsible for the government in Dubai, became the ruler. Soon after he became a ruler, Sheikh Rashid established a municipal council, which later became the basis for the municipal administration, for which task a qualified clerk was recruited from Sudan [16]. By 1961, the three sections of this municipality employed 40 staff members and 120 laborers, and had a budget of 300,000 Rupees, of which 40,000 Rupees were subsides and 260,000 Rupees were derived from tax revenues [17].

In the early establishment of Dubai Municipality, and in accordance with the traditional Arab desert style democracy, which grants the leader authority, his Highness the ruler directed and controlled all developments personally, with the help of informal committees and representatives of all interests concerned in each project. The municipality was responsible for engineering, licensing trades and business, public health, fire-fighting provisions and the work of the gardening department [18].

Establishment of Dubai Municipality can be seen as a step toward setting up a governmental institutional system and formal regulations in favor of trade development [19]. The Municipality was responsible for enforcing local orders and notices to regulate trade, improve conditions and provide opportunities to new developments in the trade business; which was reflected in the first set of local orders of the Dubai Municipality in 1961. The Municipality was concerned about controlling new construction. The local order \#13 included regulations on new construction and existing buildings. It regulated the urban expansion of buildings and lands assigned to trade, and building notices and permits on the type and location of new construction.

The first decree issued was in 1957, defining a list of 23 members appointed to the council, most of whom were well-known merchants in Dubai, due to their wider knowledge on daily issues and their advice about future plans for Dubai. In its second meeting, the Dubai Municipal Council had taken 22 decisions: six decisions on how to increase revenue (building permits, movies, alcohol, parking), four decisions on relocating some uses, three decisions about upgrading health conditions such as regulation of sanitary inspection holes, firefighting cars; and three decisions for improving infrastructure: building roads, improving the lighting network, and a proposal for laws and regulations to control the rapid city transformation [20]. 


\section{JOHN HARRIS PLANS}

The necessity to have good infrastructure and plan further development of the town led to the engagement of a British firm architect and town planner, John Harris, who was involved in shaping Dubai city for 10 years, starting from his first master plan 1960, then updating his proposal in 1965 and a new one again in 1970. The reason for having several master plans in a short time was to enable the city to respond to the unexpected growth of the population, which was beyond the estimated future expansion.

In 1959, Dubai did not have much infrastructure [21]. John Harris' 1959 plan focused on improving infrastructure, health, educational housing, schools, and trade and commerce construction, to ensure that Dubai took its place as a modern, thriving city. His sketch map was the first map to fuse the present and past. The proposed road system was an extension of an already existing axis in the historic core around the creek, allowing for its integration with future development. John Harris' map was not a conventional approach to planning. It is more of a series of roads onto the desert, as one way of anticipating very rapid development. A development committee was formed at the municipality, to assist in realization of the plan. The committee included John Harris and the senior representative of Sir William Halcrow and Partners, who administered the town planning on behalf of the Municipality for four years. The main aim was to direct public services and control building development in accordance with Harris' proposed developmental framework [22].

John Harris' deep understanding of contextual conditions was reflected in how he reinterpreted the structure of the old city and achieved an urban continuity. His proposed plan for Dubai was mainly about extending the city into the desert. It did not erase the old town, but instead created a new order of orthogonal grids and roads, based on the existing scale of the old street pattern. Between 1960 and 1971, land reclamation and the deepening of the creek's channels proceeded, allowing coasters of up to 800 tons to use creek facilities. The dredging of the creek, mainly at its entrance, was a necessary condition to maintain the port and commercial activities that had existed throughout the past. The main purpose of the developmental plan prepared by John Harris in 1971 was to give suggestions to assist in guiding development during the next coming years. In this regard, John Harris noted:

"His Highness Sheikh Rashid Bin Saeed Al Maktoum, ruler of Dubai, has great wisdom in promoting the planning of Dubai, and in ensuring that opportunities were readily available for the achievement of the planning aims. His farsighted [vision] has been abundantly justified by the results to date, and by the prosperous and secure promise of Dubai future" [23].

\section{CHALLENGES}

In his 1971 plan, John Harris attempted to identify key problems, and made recommendations concerning certain of them. For others, it was not possible to reach a conclusion without the benefit of surveys and research; so he suggested that some research and surveys should be undertaken. For John Harris, the physical character of Dubai possessed unique traditional and urban spatial qualities centered on the creek, that should be considered in any developmental plans for Dubai. He wrote:

"The physical character of Dubai has been determined by a variety of factors: its setting on the creek; the relatively flat terrain; the compact intimacy of scale of the building with informal meandering walkways between, the relatively low roofline broken by the decorated square wind towers thrusting upward to catch each breath of air movement. From natural response to particular 
problems of climate and geographical consideration, there has emerged [a] rich and appropriate local vernacular of building form and details. This vernacular has an intrinsic value, an undeniable attraction, and unquestionable harmony: one of which are measurable, but all of which contribute to the fascination exerted by Dubai and its creek" [24].

On the other hand, the rapid development that happened in the 1960s had brought many benefits and vastly improved the quality of life; and the efforts being made in education, health, housing and schools, and in trade and commerce, ensured that Dubai took its place as a modern, thriving city; however, this rapid development could be dangerous where the increasing rate of growth and change would not allow time for new ideas and new building forms to be absorbed and integrated happily into what already existed. To achieve integration, demands between the conservation of the historic fabric and development should happen. John Harris stressed the need to have a degree of conservation, where the preservation of the best of the old buildings was part of a living process in which good new buildings was encouraged [24]. For that reason, he suggested implementing a survey of old buildings worthy of preservation, and/or restoration to ensure future development is based on a policy involving conservation.

Conservation, according to Harris, implies a resolution of conflicting activities, and this is seen to be essential if a good environment is to result. Convenience for vehicles must be offset against the protection of the environment from bad effects. Conservation demands an understanding of the various factors that merge together, and add interest and richness to the vernacular. These factors are difficult to identify, often impossible to isolate and cannot be qualified, yet they provide the key to the varying degrees of attraction offered by different cities, towns and villages. Observation of Old Dubai and Deira (still seen in the Bastakiya area) leads to an appreciation of certain factors that contribute to their appeal:

- The scale of buildings and the defined spaces between buildings relate readily to the scale of the human being.

- The tight grouping of buildings leads to sharp and welcome contrast between the natural and manmade environment.

- Unity is achieved by considerable variation within restricted limits, of: size, height, proportions and patterns.

- Monotony is avoided by considerable variation, within restricted limits, of: size, height, proportions and patterns.

The 1971 plan highlighted concerns related to specific issues to be tackled in the future:

- Land ownership: The shapes of the existing plots are often not related to road networks, and are very irregular; thus, there is a need to pursue a complete survey of all privatelyowned land, to be recorded in the town map.

- Planning control and building regulation: It's important that many adopted regulations shall be readily understood. It's the Municipality's responsibility to keep the public informed, not only on the regulations, but also about the reasons justifying their adoption.

- Staff: There is a need to expand the municipality's capacity to have technical staff expert in planning, to enhance coordination and follow-up with new projects prepared by consultants.

- Coordination and phasing: If development is to proceed in an orderly and efficient manner, there should be phased coordination. Much of the information used will be 
based on forecasts, these require constant appraisal to see how reality varies from forecast, so that adjustments may be made accordingly.

Recommendations suggested by John Harris that might have assisted in guiding the continuing development along reasonable lines would focus on improving the roads and transportation infrastructure, public services and economic structure; as well as the legislation and urban planning regulations. These were grouped as follows:

1. Road network, vehicle ferries, car parking provisions, harbor, public transportation.

2. Industry, tourism and hotels.

3. Housing, medical services, educational facilities, government and civic amenities, library, museums, sport facilities, open spaces; planning, fire service and postal services.

4. Special focus should be made on the height of buildings, Deira Gulf cornice and Sharjah road development.

\section{CONCLUSIONS}

One of the key players in shaping the physical urban environment of Dubai in the second half of the 20th century is Dubai Municipality. It has played a prominent part in the successful planning of Dubai. The ruler established a municipality, controlled by a council of leading merchants; with considerable freedom of action to assist in the development of Dubai. The Municipality prepares its budget, collects municipal taxes, and submits to the Ruler through the council chairman, with requests for subsidies for major municipal works.

John Harris addressed the most important issues in his developmental plans, which are: the direction of future expansion of the city and the street system. His plan was a reflection of why Sheikh Rashid selected him to carry out this mission. His understanding and awareness of the logic of the current context enabled him to integrate the historic core of Dubai, the most important driving force of the economy in Dubai, into the future growth of the city [25]. John Harris grappled with the limited resources, but still managed to understand the context. The new proposed developmental plan by John Harris was an attempt to respond to the challenges that were raised from continuous development and HH Sheikh Rashid's guidance through the Dubai Municipality, to consider several issues of influence in the future. He raised attention to the fact that developing Dubai should still be centered on the creek. The focus should be on both the functional and the aesthetic aspects, to achieve integration of conservation of the historic buildings as part of a living process, in which good new buildings are encouraged.

One final word: few countries have changed as rapidly in the course of one generation, as United Arab Emirates. The development of Dubai stands as an example that, given the right circumstances, it is possible for a community of merchants on the Persian Gulf's Trucial Coast to reach out beyond the resources of their own immediate environment.

\section{REFERENCES}

[1] Fatma, S., Merchants' role in changing society: The case of Dubai 1900-1990. Middle Eastern Studies Journal, 34(1), pp. 87-102, 1998.

[2] Tod, R., Uncommon Dubai, ed. S. Inayat, Doura Bouhara: Malta, 2008.

[3] Dubai Statistics Department, www.dsc.gov.ae.

[4] Frauke, H.B., From Trucial States to United Arab Emirates, A Society in Transition, Motivate, 1982.

[5] Qasem, S., Sanawat Elbena Wattahawol [Arabic], Dubai Municipality Publication, 2002. https://hub.dm.gov.ae/index.html. 
[6] Fuad, M., The new Arab metropolis: A new research agenda. The Evolving Arab City: Tradition, Modernity and Urban Development, ed. S. Yasser, Routledge, 2011.

[7] Sassen, S., The Global City, Princeton University Press: Princeton, 2001.

[8] Castells, M., The Rise of Network Society, Blackwell: Oxford, 1996.

[9] Shami, S., Amman is not a city: Middle Eastern cities in question, Report for Social Science Research Council, New York, 2005.

[10] Halem, C.M., Persian Gulf states: A country study, Washington GPO report for the Library of Congress, 1993.

[11] Bahrain history: Tribal nature of Gulf society, 2001. https://workmall.com/wfb2001/ bahrain/bahrain_history_tribal_nature_of_gulf_society.htm.

[12] Belgrave, J.H.D., A brief survey of the history of the Bahraini Islands. Journal of the Royal Central Asian Society, 39, pp. 57-68, 1952.

[13] Mariam, C., Tribal Modern, University of California Press, 2004.

[14] Manamah Municipality in Bahrain. www.mun.gov.

[15] Mahjoob, Y., Contemporary architecture in Kuwait. Al Binaa Magazine, 2006.

[16] Kuwait Municipality, www.baladia.gov.kw/sites/ar/Pages/main.aspx.

[17] Maha, A. \& Salman, S., The sustainability potential of traditional architecture in the Arab world - with reference to domestic buildings in the UAE. Doctoral thesis, University of Huddersfield, 2007.

[18] Dubai Municipality, www.dm.gov.ae/en/Business/PlanningAndConstruction/ GeographicInformationSystems/Pages/GIS-Services.aspx.

[19] Qasem, H. \& Rashid, Soorah an bud [Arabic], 2007.

[20] Fenelon, K., The United Arab Emirates, An Economic and Social Survey, Longman: London, 1973.

[21] Minutes of meeting of municipal council, https://hub.dm.gov.ae/index.html.

[22] Samia, R., Seascape Urbanism along Khor Dubai: Protecting the "Port in City" as a World Heritage Site, 2015.

[23] Dubai municipality records, https://hub.dm.gov.ae/index.html.

[24] John Harris Master Plan 1971, Report: A document submitted to Dubai Municipality. https://hub.dm.gov.ae/index.html.

[25] www.dubaiasitusedtobe.net/pagesnew/JohnHarrisMasterPlanner. 